\title{
An Analysis of the Lipolysis in vitro of Obese-Hyperglycaemic and Diabetic Mice
}

\author{
Jean Steinmetz, Linda Lowry, and Terence 'T.T. Yen \\ Biological Research Division, The Lilly Research Laboratories, Eli Lilly and Company, \\ Indianapolis, Indiana 46206 (U.S.A.) \\ Received: November 14, 1968
}

Summary. Mice homozygous for either the obese gene in linkage group XI or the diabetes gene in linkage VIII exhibit syndromes similar to those of diabetes mellitus in man, including obesity and hyperglycaemia. A study of the lipolysis in vitro of the epididymal adipose tissue of 5 genotypes of mice, namely, $o b / o b, o b / o b^{+}, o b^{+} / o b^{+}$, $d b / d b$, and $d b^{+} / d b^{+}$, demonstrates that the mutant homozygotes respond differently from wild type homozygotes to various lipnlytic agents. The agents tested were epinephrine, norepinephrine, isoproterenol, corticotropin 124 , theophylline and $\mathrm{N}^{6}, \mathrm{O}^{2}$-dibutyryl-cyclic-adenosine. $3^{\prime}, 5^{\prime}$-monophosphate. The response of $a b / o b^{+}$tissue was the same as that of $o b^{+} / 0 b^{+}$tissue. The data indicate that there is a defect with respect to lipolysis in $o b / o b$ and $d b / d b$ mice. This is discussed in light of the involvement of cyclic AMP.

Une Analyse de la Lipolyse in vitro de Sounis Obèses Hyperglycémiques et Diabétiques

Résumé. Les souris homozygotes (que ce soit le gène obèse du groupe XI ou le gène diabétique du groupe VIII) présentent des syndromes semblables à ceux du diabète sucré chez l'homme, y compris obésité et hyperglycémie. Une étude de la lipolyse in vitro du tissu adipeux épididy-

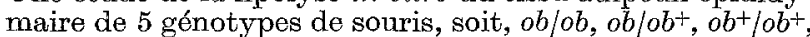
$d b / d b$, et $d b^{+} / d b^{+}$, démontre que la réaction des homozygotes mutants à divers agents lipolytiques diffère de celle des homozygotes normaux. Les substances étudiées ont été l'adrénaline, la noradrénaline, l'isoprotérénol, la cor. ticotropine $1-24$, la théophylline et le $\mathrm{N}^{6}, \mathrm{O}^{2}$-dibutyryl- cyclique-adénosine- $3^{\prime}, 5^{\prime}$-monophosphate. La réponse des tissus $o b / o b^{+}$est la même que celle des tissus $o b^{+} / o b^{+}$. Les données indiquent qu'il existe un trouble de la lipolyse chez les souris $o b / o b$ et $d b / d b$. Ceci est examiné à la lumière du rôle joué par l' AMP cyclique.

Untersuchungen der Lipolyse in vitro bei der fettsüchtighyperglykämischen und der diabetischen Maus

Zusammenfassung. Mäuse, die entweder für Fettsucht (ob) in der Verbindungskette XI oder für Diabetes (db) in der Verbindungskette VIII homozygot sind, weisen Syndrome auf, die denen des menschlichen Diabetes mellitus ähnlich sind. Das bezieht sich auch auf Fettsucht und Hyperglykämie. Eine Untersuchung der in vitro Lipolyse der epididymalen adipösen Gewebe von 5 Mausgenotypen, $o b / o b, o b / o b^{+}, o b^{+} / o b^{+}, d b / d b$ und $d b^{+} / d b^{+}$, zeigte, daß mutante Homozygoten anders auf lipolytische Mittel reagieren als homozygote Typen der Wildform. Die geprüften Wirkstoffe waren Adrenalin, Noradrenalin, Isoproterenol, Corticotropin 1-24, Theophyllin und $\mathrm{N}^{6}, \mathrm{O}^{2}$-Dibutyrylzyklo-adenosin $3^{\prime}, 5^{\prime}$-monophosphat. Die Reaktionen des $a b / o b^{+}$Gewebes und des $a b^{+} / o b^{+}$Gewebes sind gleichartig. Die Ergebnisse deuten auf einen Defekt der Lipolyse bei $o b / o b$ und $d b / d b$ Mäusen hin. Die Bedeutung des cyclischen AMP in dieser Hinsicht wird diskutiert.

Key-words: Lipolysis, obese hyperclycaemic mice, diabetic mice, spontaneous diabetes, adipose tissue in vitro, catecholamines, cyclic AMP, dibutyryl cyclic AMP theophylline, $a b$ gene, $d b$ gene, fatty acid mobilization, mouse plasma fatty acid.

\section{Introduction}

Syndromes similar to those of diabetes mellitus in man are produced in mice by both the obese and the diabetes mutations. These two autosomal recessive mutations arose spontaneously in Jackson Laboratory mice $[11,9]$. The $o b$ gene of linkage group XI originated in Stock $V$ mice and has been maintained in the highly inbred $\mathrm{C} 57 \mathrm{BL} / 6 \mathrm{~J}$ strain (6). The $\mathrm{C} 57 \mathrm{BL} / \mathrm{KsJ}$ strain gave rise to and is presently carrying the $d b$ gene in linkage group VIII [12]. A great many studies, reviewed by Meier [17] and Hellman [8], have been undertaken to compare the metabolism of the obese $(o b / o b)$ mouse with that of its normal littermate $\left(a b^{+} / a b^{+}\right)$. Little work on the heterozygote $\left(o b / o b^{+}\right)$has been done. The general characteristics of the diabetic mouse $(d b / d b)$ and the development of its disorder have been documented by Coleman and Hummer [2]. Although no lipolysis studies of the diabetic mouse have been reported, it has previously been found that obese mouse adipose tissue or isolated fat cells exhibit an impairment of epinephrine- or norepinephrine-stimulated fatty acid mobilization $[13,16,18]$. It has been specu- lated that the lack of response of this tissue to catecholamines may be of major aetiological significance [16].

RANDLE has proposed that several disorders, including obesity and diabetes, are a result of high plasma free fatty acid (FFA) concentrations [19]. Abnormal carbohydrate metabolism thereby would be reduced to the status of a secondary effect of this "fatty acid syndrome".

Cyclic adenosine- $3^{\prime}, 5^{\prime}$-monophosphate (cyclic AMP) has recently been singled out as a mediator of many hormonal effects. One such effect is the stimulation of lipolysis - a function it presumably accomplishes by activating lipase, the rate-limiting enzyme in triglyceride degradation [20]. Catecholamines are thought to stimulate FFA mobilization by acting on adenyl cyclase (possibly located at the membrane receptor site for the hormone), thereby raising the intracellular level of cyclic AMP. The effect of ACTH is likewise mediated by cyclic AMP, although its receptor site may not be the same as the one for catecholamines [15]. Theophylline stimulates lipolysis by inhibiting the phos- 
phodiesterase which catalyzes the conversion of cyclic AMP to 5'-AMP [20].

In the light of these current findings, we felt it necessary to investigate the lipolysis in vitro of the epididymal adipose tissue of the obese mouse by measuring the production of FFA in the presence of catecholamines, ACTH, theophylline or cyclic AMP. We also studied the tissue responses of the ob/ob+heterozygote and compared the obese tissue with that of the similar diabetic mice and their controls.

\section{Materials and Methods}

\section{Chemicals}

The sources of chemicals were as follows: bovine albumin (fraction V powder, fatty acid poor, Pentex); ACTH 1-24 (synthetic corticotropin 1-24, a gift from Dr. S.A. Szpilfogel of Organon, Holland); $\mathrm{N}^{6}, \mathrm{O}^{2}$-dibutyryl-cyclic-adenosine- $3^{\prime}, 5^{\prime}$-monophosphate (Boehringer Mannheim); I-epinephrine bitartrate and L-norepinephrine bitartrate (Nutritional Biochemicals); Glucostat (Worthington); isoproterenol (Eli Lilly); oleic acid and theophylline (Mann); protein standard solution-bovine albumin (Armour); sodium diethyldithiocarbamate (Eastman); Trizma base (Sigma).

\section{Mice}

All five genotypes of mice used in this study were supplied and identified by the Jackson Laboratory, Bar Harbor, Maine. The genotypes were $o b / o b, o b / o b^{+}$, and $o b^{+} / o b^{+}$of the C57BL/6J strain, and $d b / d b$ and $d b^{+} / d b^{+}$of the C57 BL/KsJ strain. Most of the mice used were 3 to 5 months of age. They were fed ad libi. tum with Purina mouse chow until killing.

\section{Lipolysis}

Mice were killed by $\mathrm{CO}_{2}$ asphyxiation and exsanguinated by cardiac puncture. This method does not affect our results differently from killing by decapitation. The epididymal adipose tissue was removed immediately and rinsed in Krebs-Ringer bicarbonate buffer [3]. Six mice of one genotype were used in each experiment. $100 \pm 20 \mathrm{mg}$ of tissue from each mouse was incubated at each concentration tested in a given run. Each tissue sample was incubated in a $30 \mathrm{ml}$ glass serum vial containing $2.9 \mathrm{ml} \mathrm{3} \%$ albumin in KrebsRinger bicarbonate buffer, $\mathrm{pH} 7.25 .0 .1 \mathrm{ml}$ of a $0.1 \mathrm{M}$ tris, $\mathrm{pH}$ 7.4, solution of the compound of interest was added to each flask just prior to incubation. The preparation of the theophylline media was the only exception to this procedure: because of its low solubility, this compound was dissolved directly in the KrebsRinger bicarbonate buffer-albumin medium at the concentration desired, stirred overnight in the cold, and used undiluted as the total $3 \mathrm{ml}$ medium. After a 90 minute incubation at $37^{\circ} \mathrm{C}$ in a Dubnoff shaker (about 80 cycles per minute) under an atmosphere of $95 \% \mathrm{O}_{2}-5 \% \mathrm{CO}_{2}$, the tissue from each flask was washed twice in distilled water, homogenized in $1 \mathrm{ml}$ Dole's mixture [4], extracted and assayed for FFA content. 1 or $2 \mathrm{ml}$ of the incubation medium was also extracted. and assayed.

\section{FFA extraction and assay}

The FFA of tissue and medium was extracted by a modification of Dole's method [4], and assayed by the copper soap method of Duncombe [5] as follows: medium or tissue homogenate was extracted with a total of $5 \mathrm{ml}$ Dole's mixture, $5 \mathrm{ml} \mathrm{n}$-heptane and $3 \mathrm{ml}$ water. After this mixture was thoroughly shaken and allowed to settle, $4 \mathrm{ml}$ of the heptane phase was transferred to a glass centrifuge tube and evaporated to dryness with nitrogen in a $45^{\circ} \mathrm{C}$ water bath. Four ml $\mathrm{CHCl}_{3}$ and $2.5 \mathrm{ml}$ Duncombe's copper reagent were then added; the tubes were mixed and centrifuged at $733 \times \mathrm{g}$ for 5 minutes in a Sorvall GLC-1 centrifuge. After aspiration of the copper reagent, $3 \mathrm{ml}$ of the remaining $\mathrm{CHCl}_{3}$ solution was transferred to a tube containing $0.5 \mathrm{ml}$ diethyldithiocarbamate colour reagent. A Spectronic 20 (Bausch \& Lomb) was used to determine the $440 \mathrm{~m} \mu$ optical density of samples and oleic acid (>99\% pure) standards. This same extraction and assay were used to determine plasma FFA on $0.1 \mathrm{ml}$ of pooled plasma samples obtained by tail bleeding into heparinized capillary tubes.

\section{Blood glucose assay}

Blood glucose levels were determined with Glucostat, using a slight modification of Worthington's original procedure [22] $0.05 \mathrm{ml}$ of blood was diluted to 2 $\mathrm{ml}$ with water. To this was added $1 \mathrm{ml}$ each $0.1 \mathrm{~N}$ $\mathrm{NaOH}$ and $2.0 \% \mathrm{ZnSO}_{4} .7 \mathrm{H}_{2} \mathrm{O}$, with mixing after each addition. After filtration through Whatman No. 1 filter paper, $1 \mathrm{ml}$ of the deproteinized filtrate was assayed for glucose. Worthington's $4 \times$ Chromogen and Glucostat were each dissolved, as supplied, in $100 \mathrm{ml}$ distilled water. One $\mathrm{ml}$ of each of these solutions was added to the $1 \mathrm{ml}$ filtrate and incubated for $30 \mathrm{~min}$ at $37^{\circ} \mathrm{C}$. One drop of $4 \mathrm{~N} \mathrm{HCl}$ was then added to stop the reaction. After five minutes, the optical density at $400 \mathrm{~m} \mu$ was determined with a Spectronic 20.

\footnotetext{
Abbreviations

eyclic AMP: cyclic adenosine- $3^{\prime}, 5^{\prime}$-monophosphate dibutyryl cyclic AMP: $\mathrm{N}^{6}, \mathrm{O}^{2}$-dibutyryl-cyclicadenosine- $3^{\prime}, 5^{\prime}$-monophosphate

$d b$ : the gene diabetes (linkage group VIII)

$o b$ : the gene obese (linkage group XI)

tris: tris (hydroxymethyl)aminomethane-HCl

FFA: free fatty acid or non-esterified fatty acid.

\section{Results}

Body weight and blood glucose

Obese and diabetic mice at the age used in this study are approximately twice as heavy as normal and heterozygous mice. Table 1 presents a comparison of
} 
the blood glucose levels of these 5 types of mice. Normal mice and ob/ob+ heterozygotes exhibied a similar blood glucose level, whereas that of obese mice averaged
Response to catecholamines and $A C T H$

Catecholamines and ACTH are known to cause elevation of the level of cyclic AMP in adipose tissue [20].

Table 1. Blood glucose level $(\mathrm{mg} / 100 \mathrm{ml})$ of the five types of mice

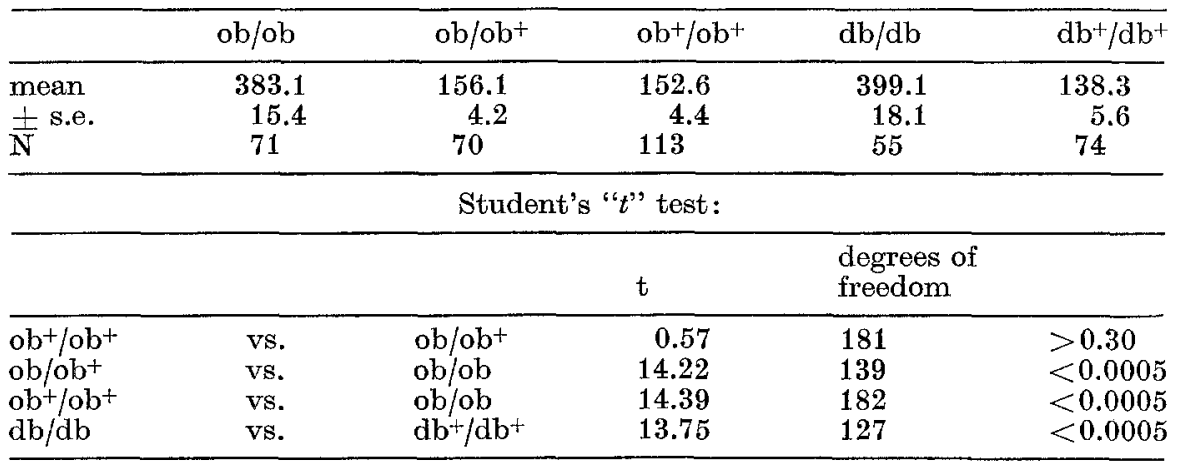

a Average of values for mice used in these lipolysis experiments.

more than twice as high. The blood glucose level of diabetic mice was nearly three times that of their controls.

\section{Basal lipolysis}

The basal lipolysis rate of the adipose tissue of diabetic mice was the same as that of the control mice (Table 2). Obese mouse tissue had a basal rate lower than that of normal mice and, interestingly, the same as that of the heterozygote. Plasma FFA values

Table 2. Basal lipolysis rate in umoles FF A/100 mg tissue/90 min (mean \pm s.e.)

\begin{tabular}{llll}
\hline & medium & tissue & total \\
\hline $\mathrm{ob}^{+} / \mathrm{ob}^{+}$ & $0.19 \pm 0.02$ & $0.19 \pm 0.02$ & $0.39 \pm 0.03$ \\
$(\mathrm{~N})$ & $(29)$ & $(29)$ & $(29)$ \\
$\mathrm{ob} / \mathrm{ob}^{+}$ & $0.10 \pm 0.01$ & $0.13 \pm 0.02$ & $0.23 \pm 0.03$ \\
$(\mathrm{~N})$ & $(29)$ & $(\mathbf{3 0 )}$ & $(30)$ \\
$\mathrm{ob} / \mathrm{ob}$ & $0.13 \pm 0.00$ & $0.13 \pm 0.00$ & $0.27 \pm 0.00$ \\
$(\mathrm{~N})$ & $(19)$ & $(18)$ & $(18)$ \\
$\mathrm{db}+/ \mathrm{db}+$ & $0.14 \pm 0.01$ & $0.27 \pm 0.03$ & $0.41 \pm 0.04$ \\
$(\mathrm{~N})$ & $(34)$ & $(36)$ & $(35)$ \\
$\mathrm{db} / \mathrm{db}$ & $0.15 \pm 0.02$ & $0.28 \pm 0.00$ & $0.43 \pm 0.03$ \\
$(\mathrm{~N})$ & $(24)$ & $(24)$ & $(24)$ \\
\hline
\end{tabular}

Table 3. Plasma fatty acid expressed as umoles FWA/ml plasma ${ }^{\mathrm{a}}$

$\begin{array}{ll}\mathrm{ob}^{+} / \mathrm{ob}^{+} & 1.10 \pm 0.16 \\ \mathrm{ob} / \mathrm{ob}^{+} & 0.90 \pm 0.14 \\ \mathrm{ob} / \mathrm{ob} & 1.65 \pm 0.17 \\ \mathrm{db} / \mathrm{db} b^{+} & 0.81 \pm 0.04 \\ \mathrm{db} / \mathrm{db} & 1.86 \pm 0.27\end{array}$

a Each determination is on the pooled plasma from $6-10$ mice of each genotype. The same animals were not necessarily used for lipolysis runs. The data presented in this table are the mean 1 s.e. from 4 determinations.

(Table 3) did not follow the same pattern. Obese mice showed a higher plasma FFA level than normal and heterozygous mice, and diabetic mice likewise had a higher level than their controls.

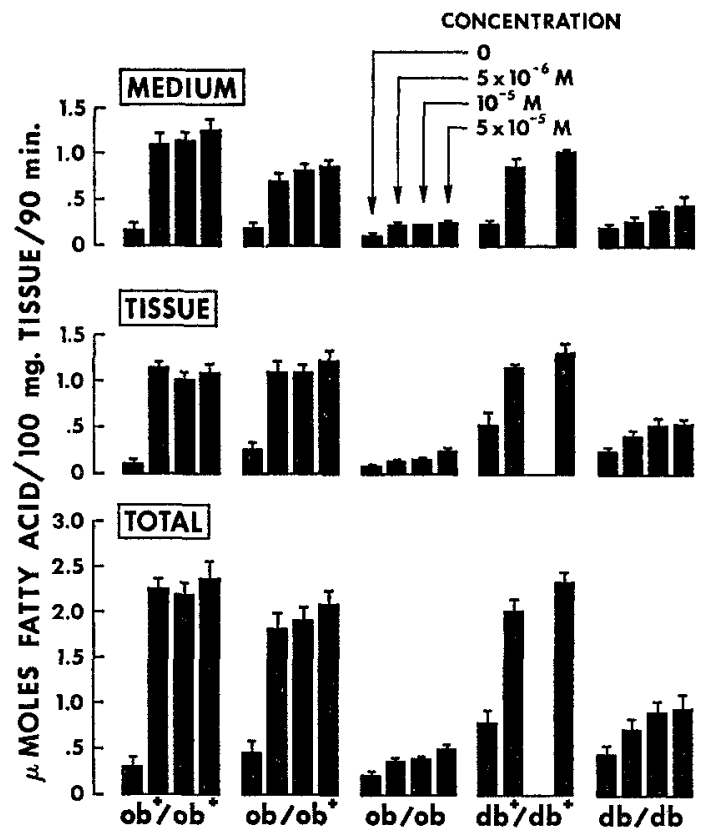

Fig. 1. The effect of epinephrine on epididymal adipose tissue lipolysis. Medium, tissue and total umoles FFA/ $100 \mathrm{mg}$ tissue $/ 90 \mathrm{~min}$ are presented for each of the five types of mice tested. In this and the following figures, the three graphs for each genotype represent the data (mean \pm s.e.) of a typical experiment involving six mice. The tissue from each mouse was divided into a sufficient number of pieces to allow the testing of the response of every animal used to all of the concentrations indicated

The stimulation of lipolysis seen with epinephrine at $5 \times 10^{-6}, 10^{-5}$, and $5 \times 10^{-5} \mathrm{M}$ is shown in Fig. 1. These concentrations are apparently such that maximal stimulation was achieved, since there was little dose response in this concentration range. In the production of FFA, control mice and heterozygotes far exceeded the homozygous mutants in response to epinephrine. The FFA mobilization of the obese mouse was almost unaffected, and that of diabetic mice was stimulated 
slightly. The same general picture of almost no response of obese and low response of diabetic mice was seen with norepinephrine or isoproterenol at $5 \times 10^{-6} \mathrm{M}$ (Fig. 2).

Response of the five types of adipose tissue to ACTH was tested using corticotropin 1-24, a synthetic peptide which has the lipolytic activity of native porcine ACTH [7], but lacks the many impurities we have found by polyacrylamide gel electrophoresis of some commercial ACTH preparations. This synthetic corticotropin 1-24 did stimulate FA mobilization by adipose tissue from control and heterozygous mice at 20 and 100 milliunits/ml (Fig. 3). It caused minimal lipolytic stimulation in obese tissue, and diabetic tissue exhibited a slight response.

\section{Response to theophylline and cyclic $A M P$}

As has been previously reported, theophylline activates lipolysis in normal mice to an even greater extent than the catecholamines [10]. Diabetic and obese mice likewise showed a response to theophylline $\left(10^{-3}, 5 \times 10^{-3}\right.$, and $\left.10^{-2} \mathrm{M}\right)$, although once again theirs was not so great as the response of the normal mice (Fig. 4). Activation of FA mobilization - presumably an indication of degree of phosphodiesterase inhibition - reached a plateau between $5 \times 10^{-3}$ and $10^{-2} \mathrm{M}$ in all five types of mice.

Since the cell membrane is scarcely permeable to cyclic AMP itself, its lipolytically active and more permeable derivative, dibutyryl cyclic AMP [1], was tested for its effect on lipolysis. The adipose tissue was incubated with $10^{-4}, 5 \times 10^{-4}, 7.5 \times 10^{-4}$, and $10^{-3} \mathrm{M}$ dibutyryl cyclic AMP. All five types of adipose tissue reached a plateau of $\mathrm{FA}$ mobilization in this range in general, at about $5 \times 10^{-4} \mathrm{M}$. The maximal degree of response elicited by dibutyryl cyclic $A M P$ is equal to that in the plateau region of theophylline stimulation for obese and diabetic mice, and is equal to or possibly higher than the theophylline plateau for the normal and heterozygous animals studied (Fig. 5).

Unlike the catecholamines and ACTH, theophylline and dibutyryl cyclic AMP stimulated both obese and diabetic mouse tissue to essentially the same degree.

\section{Discussion}

The differences in the basal lipolysis rates in vitro of mutant and normal homozygote adipose tissue are surprisingly small in comparison with the dissimilarity in plasma fatty acid level (but see [21]). We should conclude that the true basal rate of these normal and mutant mouse tissues may not differ so greatly as the dissimilarity of the tests in vivo indicates. HELLMaN has reported that the adipose tissue of obese mice contains more mast cells and larger fat cells than the normal mice [8]. As a result, data presented on a tissue weight basis or even on a protein nitrogen basis would necessarily vary somewhat for normal and homozygous mutant mice because of the smaller number of fat cells in the obese mouse tissue.
Our finding that obese and diabetic mouse tissue responds only slightly to catecholamines agrees with the results of other studies of the adipose tissue [6] and the isolated fat cells [18] of obese mice. The basal lipolysis rates which MaRsHaLL and ENGEL [6] reported differ greatly from ours, however, because their incubation medium included glucose. We chose not to add glucose to our media since it enhances the reesterification of mobilized FFA [14] and is metabolized differently by control and mutant tissues [13]. In fact, for $a b^{+} / a b^{+}, a b / o b^{+}$, and $a b / o b$ tissue, a gene dosage effect in relation to glucose metabolism is found - the $o b$ gene reduces the amount of glucose oxidized to $\mathrm{CO}_{2}[23]$.

The catecholamines and ACTH are thought to stimulate lipolysis by acting on adenyl cyclase to increase the production of cyclic AMP [20]. Since the obese and diabetic mouse tissue responds only slightly to these agents, it would seem possible that they may have a defective adenyl cyclase system. That adenyl cyclase is indeed present is indicated by our finding (cf. [18]) that theophylline stimulates lipolysis in the mutant animals. If no cyclic AMP were being made, blockage of its breakdown by phosphodiesterase would not cause it to accumulate and stimulate lipolysis. It is likewise apparent that an excess of phosphodiesterase is not the sole cause of the abnormalities of these mutant homozygotes. If such were the case, theophylline would be expected to eliminate the differences between the rates of lipolysis of mutant and control mice at a concentration which entirely inactivates that enzyme (presumably any concentration which shows maximal stimulation of lipolysis). At the higher theophylline concentrations, however, no approach to similar rates of lipolysis for mutant and control animals is found. Such a conclusion, of course, rests on the assumption that theophylline acts in the same manner on the phosphodiesterase of both mutant and control adipose tissue.

Since the response of mutant homozygote adipose tissue to dibutyryl cyclic AMP is not so great as the response of normal tissue, it is apparent that there is a defect in this metabolic pathway somewhere between cyclic AMP and the mobilized FFA. It is clear that no steps in the pathway are completely blocked, since an appreciable amount of stimulation is seen in the mutant mice. This does not eliminate the possibility that there is a limited amount of hormone-sensitive lipase in mutant tissue or that the response of lipase to cyclic AMP is altered. These last conclusions rest on two assumptions (1) that the adipose tissue of mutant and normal mice is equally permeable to dibutyryl cyclic AMP, and (2) that this derivative is metabolized in the some manner as native cyclic AMP.

In conclusion, it is apparent from these data that the lipolysis systems of both diabetic and obese mice are defective. The defect seems to involve both adenyl cyclase and lipase, and results in a decreased mobilization of FA in mutant adipose tissue compared with 


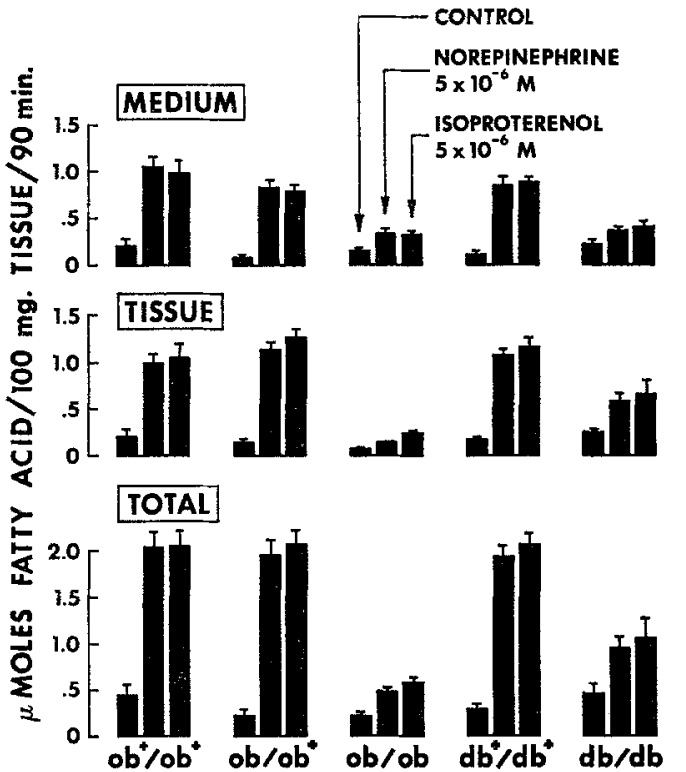

Fig. 2. The effect of norepinephrine and isoproterenol on epididymal adipose tissue lipolysis. Medium, tissue and total $\mu$ moles FFA/100 mg tissue $/ 90 \mathrm{~min}$ are repesented for each of the five types of mice tested (mean \pm s.e.)

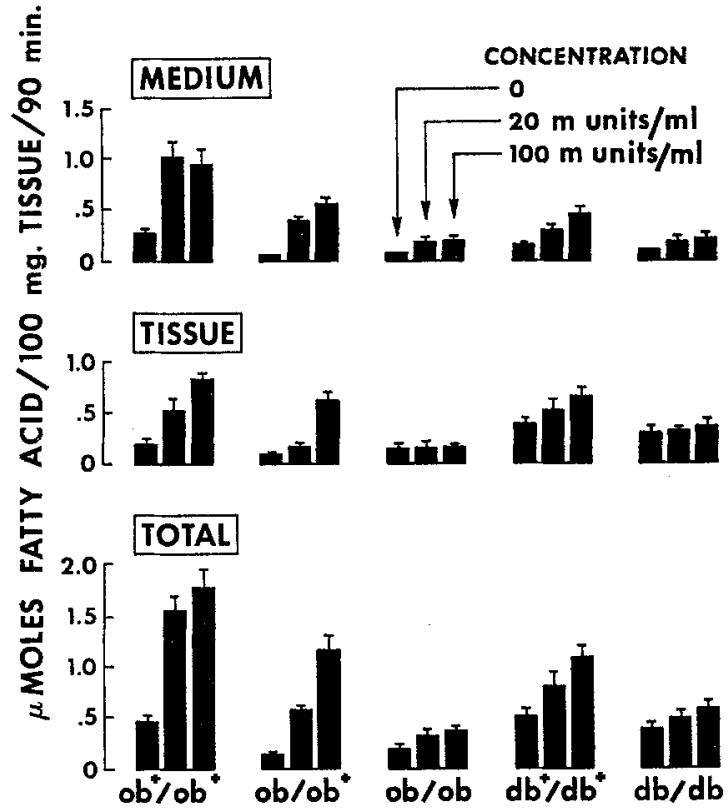

Fig. 3. Effect of ACTH 1-24 on epididymal adipose tissue lipolysis. Medium, tissue and total umoles FFA/100 mg tissue $/ 90 \mathrm{~min}$ are represented for each of the five types of mice tested (mean \pm s.e.)

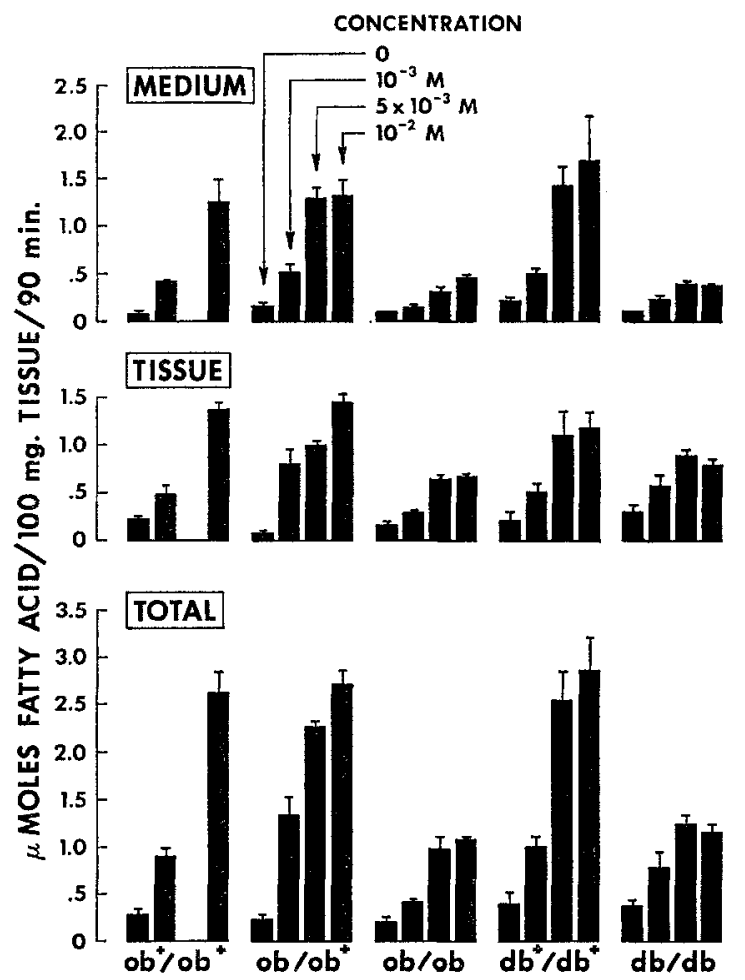

Fig. 4. Effect of theophylline on epididymal adipose tissue lipolysis. Medium, tissue and total umoles FFA $/ 100 \mathrm{mg}$ tissue/90 min are represented for each of the five types of mice tested (mean t s.e.)

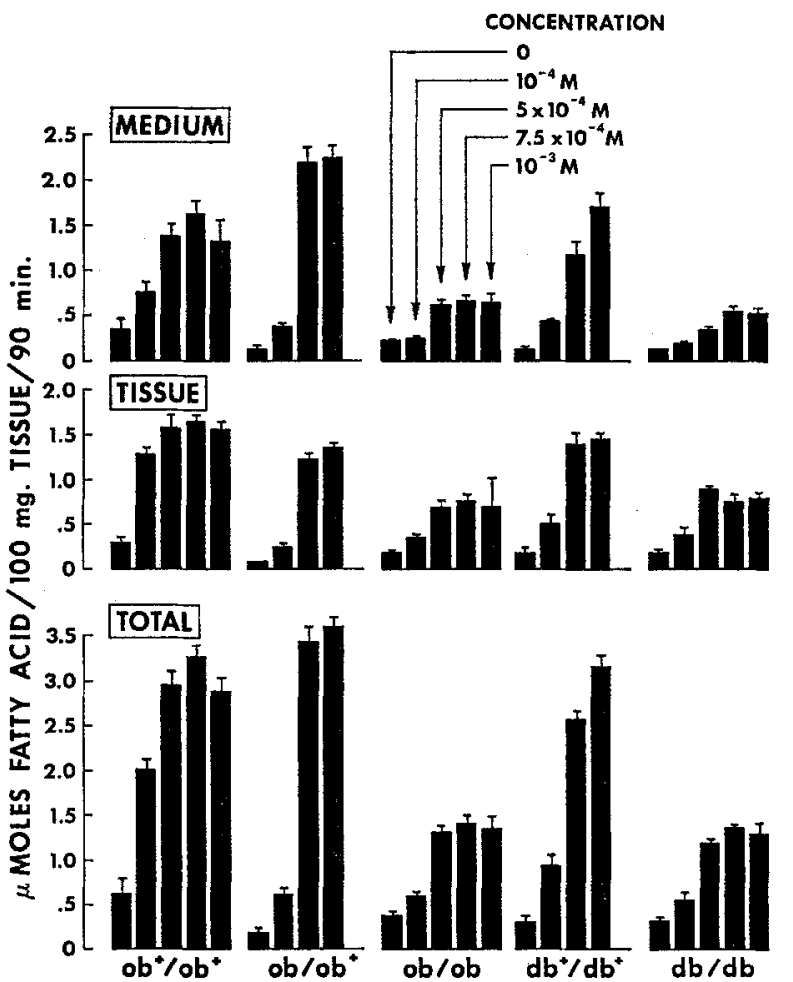

Fig. 5. The effect of dibutyryl cyclic AMP on epididymal adipose tissue lipolysis. Medium, tissue and total $\mu$ moles FFA/100 $\mathrm{mg}$ tissue $/ 90 \mathrm{~min}$ are represented for each of the five types of mice tested (mean \pm s.e.) 
the normal controls or ob/ob ${ }^{+}$heterozygotes. That the difficulty in lipolysis of obese mouse adipose tissue is probably a secondary lesion is indicated by the lack of a gene dosage effect, i.e. ob/ob+ heterozygote tissue responds to these lipolytic agents to the same degree as normal tissue. A primary lesion would be expected to exhibit a gene dosage effect such as the one we have found in the oxidation of glucose to $\mathrm{CO}_{2}$ by the adipose tissue of obese, heterozygous and control mice in vitro [23]. The relationship between altered glucose oxidation and the abnormal lipolysis of obese mice is not clear at present. The final clarification of the reasons for the altered lipolysis of mutant homozygotes awaits the direct study of the enzymes involved, i.e. adenyl cyclase, phosphodiesterase and lipases.

Acknowledgements. The authors wish to thank Professor J AMES AsHMORE, Indiana University, for his advice, Dr. S.A. SzPILFOGEL of N. V. Organon-OSS-Holland for the generous gift of ACTH 1-24, Mr. E. Diller for the modified method of Dole's extraction and Duncombe's FFA assay, and Mrs. J. M. Acron for her technical assistance.

\section{References}

1. BuTcher, R.W., R.J. Ho, H.C. MENG, and E.W. SUTHERLAND: Adenosine $3^{\prime}, 5^{\prime}$-monophosphate in biological materials. J. biol. Chem. 240, 4515-4523 (1965).

2. Coleman, D.L., and K.P. Hummel: Studies with the mutation, diabetes, in the mouse. Diabetologia 3, $238-248$ (1967).

3. DeLuCA, H.F., and P.P. CoHen: Preparation of tissues and enzymes. In W.W. Umbreit: Manometric Techniques, 4th ed., p. 131. Minneapolis: Burgess Publishing Co. 1964.

4. DoLe, V.P.: A relation between non-esterified fatty acids in palsma and the metabolism of glucose. $J$. clin. Invest. 35, 150-154 (1956).

5. Duncombe, W.G.: The colorimetric micro-determination of long-chain fatty acids. Biochem. J. 88, 7-10 (1963).

6. GretN, M.C.: Mutant genes and linkages. In E.L. Grewe, ed.: Biology of the Laboratory Mouse. 2nd edition, p. 108. New York: MeGraw-Hill Book Company 1966.

7. Gries, F.A., and H. BethGE: A comparison of the lipolytic effects of $\beta^{1-24}$-corticotropin and extracted porcine ACTH. Metabolism 16, 967-976 (1967).

8. Hellman, B.: Studies in obese-hyperglycemic mice. Ann. N.Y. Acad. Sci. 131, $541-558$ (1965).

9. Hummel, K.P., M.M. Dickre, and D.L. Coreman: Diabetes, a new mutation in the mouse. Science $\mathbf{1 5 3}$, 1127-1128 (1966).
10. Hynie, S., G. Krishna, and B.B. Brodie: Theophylline as a tool in studies of the role of cyclic adenosine $3^{\prime}, 5^{\prime}$-monophosphate in hormone-induced lipolysis. J. Pharmacol. exp. Ther. 153, 90-96 (1966).

11. Ingails, A.M., M.M. DiCKIE, and G.D. SNell: Obese, a new mutation in the house mouse. J. Heredity 41, $317-318$ (1950).

12. Lane, P.W.: Mouse newsletter 38, 24 (Feb. 1968).

13. Lezonuf, B., S. Lochaya, N. Leboevf, F.C. Wood, Jr., J. MAYER, and G.F. CAHILL, Jr.: Glucose metabolism and mobilization of fatty acids by adipose tissue from obese mice. Amer. J. Physiol. 201, 19-22 (1961).

14. - Regulation of fatty acid esterification in adipose tissue incubated in vitro. In A.E. RENOLD, and G.F. CAHIII, Jr.: Handbook of Physiology, Section 5: Adipose Tissue, p. 387. Washington, D. c.: American Physiological Society 1965.

15. LeCh, J.J., and D.N. CalverT: Some evidence for differentiation of ACTH and norepinephrine lipolytic receptors in adipose cells. Life Sci. 6, $833-844$ (1967).

16. Marshate, N.B., and F.L. EnGex: The influence of epinephrine and fasting on adipose tissue content and release of free fatty acids in obese-hyperglycemic and lean mice. J. Lipid Res. 1, 339-342 (1960).

17. MeIer, H. : Experimental Pharmacogenetics: Physiopathology of Heredity and Pharmacologic Responses, p. 33. New York: Academic Press 1963.

18. Mengen, V. K., u. U. Schwabe: Lipolyso an isolierten Fettzellen von fettsüchtigen Mäusen (obese mice). Arch. Pharmakol. Exptl. Pathol. 260, 176 (1968).

19. RaNdie, P.J., P.B. Gariand, C.N. Hales, and E. A. NewsHorme: The glucose fatty-acid cycle: its role in insulin sensitivity and the metabolic disturbances of diabetes mellitus. Lancet $1963 \mathrm{I}, 785-789$.

20. Sutherland, E.W., G.A. Robison, and R.W. But. CEER: Some aspects of the biological role of adenosine $3^{\prime}, 5^{\prime}$-monophosphate (cyclic AMP). Circulation 37, $279-306$ (1968).

21. Westman, S.: Development of the obese-hyperglycaemic syndrome in mice. Diabetologia 4, 141-149 (1968).

22. Worthington Enzymatic Diagnostic Reagents, p. 22. Freehold, New Jersey: Worthington Biochemical Corp. 1964.

23. Yen, T.T.T., L. Lowny, and J. Stwinmetz: Obese locus in Mus musculus : a gene dosage effect. Biochem. Biophys. Res. Comm. 33, 883-887 (1968).

Terence T.T. Yen. Ph. D. Biological Research Division Eli Lilly and Company Indianapolis, Indiana 46206

Note added during manuscript revision : $d b / d b+$ heterozygotes have recently become available. Preliminary results indicate that there is no difference between them and the normal mice with respect to the above mentioned parameters (body weight, blood glucose and lipolytic response). 